\title{
EFFECT OF SURCHARGE HEIGHT AND PRELOADING TIME ON LONG-TERM SETTLEMENT OF CLOSED LANDFILLS: A NUMERICAL ANALYSIS
}

\author{
MEHRNAZ ALIBEIKLOO ${ }^{1}$, HAJAR SHARE ISFAHANI ${ }^{2} \&$ HADI KHABBAZ $^{3}$ \\ ${ }^{1}$ Faculty of Engineering and IT, University of Technology, Australia \\ ${ }^{2}$ Department of Civil Engineering, Isfahan University of Technology, Iran \\ ${ }^{3}$ Faculty of Engineering and IT, University of Technology, Australia
}

\begin{abstract}
In recent years, by developing cities and increasing population, reconstructing on closed landfill sites is unavoidable in some regions. Long-term settlement is one of the major concerns associated with reconstruction on landfills after closure. The purpose of this research is evaluating the effect of preloading in various patterns of height and time on long-term settlements of closed landfills. In this regard, five scenarios of surcharge from 1 to $3 \mathrm{~m}$ high within 3, 4.5 and 6 months of preloading time have been modelled using PLAXIS 2D software. Moreover, the numerical results have been compared to those obtained from analytical methods, and a good agreement has been achieved. The findings indicate that there is a linear relationship between settlement and surcharge height. Although, long-term settlement decreased by applying a longer and higher preloading, the time of preloading was found to be a more effective factor compared to preloading height.
\end{abstract}

Keywords: preloading, long-term settlement, closed landfill, PLAXIS 2D.

\section{INTRODUCTION}

Nowadays, considering the population growth, the cities are developing, which can lead to place some closed landfill sites within urban areas. Therefore, in some cases reconstruction on closed landfill is inevitable. Roads and public transport network are most probable cases for reconstruction on the top of closed landfill sites. There are a variety of challenges related to redevelopment on the top of closed landfills including, long term settlement control and protecting the stability of landfill structure. In order to reduce the super-structure settlement, improving the settlement characteristics of waste material is necessary. Moreover, the used method for improving the mechanical properties of waste disposal should be safe for the landfill cover layer and the drainage system.

Different methods can be applied for improving the ground, including stone columns, cement grouting, chemical stabilization, dynamic compaction and preloading [1]. However, some of ground improvement methods are not appropriate for landfills as a result of heterogeneous nature of wastes and existing different landfill components such as the liner structure. As an example, intrusive improvement techniques such as dynamic compaction (DC) can destroy the landfill cover layer, which usually consist of compacted clay with a synthetic barrier or geosynthetic clay liner (GCL) as a hydraulic barrier. Among the existing improvement techniques, preloading is a safe and non-intrusive method. Preloading is applying an external load on a low-permeable soil in order to accelerate the consolidation process and increasing the effective stress [2]. Referring to [3], the process of preloading is a simple form of applying induced settlement. Since wastes in landfills have heterogeneous nature, predicting settlement, especially secondary settlement is a major challenge. Therefore, there are limited studies associated with applying preloading technique on top of landfills. The most recent case study of using preloading for landfill improvement have been presented by [4] at Fresh Kills landfill on Station Island, New York. The landfill classification was the mixture of municipal solid wastes and construction debris. According to the results 
of this research, it was concluded that the predicted settlement under the embankment was from $0.15 \mathrm{~m}$ to $1.83 \mathrm{~m}$. The initial measurements indicated that about $0.5 \mathrm{~m}$ of the predicted settlement occurred during the first 1.5 months. Moreover, the settlement parameters were calculated for wastes at Fresh Kills landfill using back analysis method, which are as follows [4]:

- The average value for modified secondary compression indices is 0.022 .

- The average values for modified primary and recompression indexes are 0.23 and 0.023 , respectively.

There is another case study at Tinton Falls landfill in New Jersey, USA [5]. In this site, both method of dynamic compaction and preloading were used aiming to improve landfill behaviour. The results of this case study illustrated that the secondary compression index was between 0.059 and 0.0817 , which was considerably different with the values presented by [4] and showed the variation of settlement parameters for different wastes in various landfill classifications. Furthermore, it is outlined that observed total and differential settlements for preloading zone was higher than those observed in the zones where dynamic compaction were applied [5].

Aforementioned, preloading is a very simple (no need to employ special equipment), nonintrusive and an effective method (even for deeper improvements); however, it is a time consuming method. Although using a vertical drainage system is a common method to decrease the time of applying surcharge, vertical drains cannot be used in the landfill because they may destroy the landfill cover layer. Vertical drains can also provide a route in which the hazardous substance can be released [6]. In order to make preloading a time effective method, increasing the height of surcharge can be proposed as a suitable alternative. Having the knowledge of long-term settlement of landfills based on time and height of preloading leads to optimize the preloading design. As a result, in this research the effect of preloading on long-term settlements in closed landfill sites, considering the time and height of surcharge, has been investigated using numerical and theoretical methods.

\section{THEORY OF SETTLEMENT}

There are a variety of factors contributing to landfill settlements including, type of waste, organic content, moisture content, compaction density, compressibility, and level of nutrients available for biological activities, $\mathrm{pH}$, temperature, and time [7]. Landfill settlement is considerably complex in comparison with coarse and fine soils as a result of heterogeneous nature of wastes, large particle sizes, compression of refuse particles, and the loss of solid due to biodegradation [8]. In addition, landfill settlements are classified into five groups [9]:

1. Initial compression: This settlement is the immediate mechanical compression caused by compression of highly deformable waste components and takes place immediately after an external load applied to the waste.

2. Primary settlement: It is the mechanical settlement due to continuous compression or reorientation of waste which is a slower process. This settlement is the consolidation settlement that occurs due to dissipation of water and gas from the pores as a result of applying the load.

3. Secondary settlement: This settlement is the mechanical compression due to the creep and primary decomposition of the waste.

4. Decomposition settlement: The settlement as a result of decomposition of organic material.

5. Residual settlement: Mechanical deformation and organic decomposition cause residual settlement. 
Fig. 1 presents the settlement stages of wastes based on categories mentioned above. According to this figure, the settlement due to the self-weight or surcharge takes place within 3 months. The settlement at stages III to V is highly substantial and is time-dependent. Decomposition settlement is considerably important at landfills with organic and putrescible materials. In this research, it has been assumed that the waste materials are old and mostly inorganic and non-putrescible. Therefore, decomposition settlement due to biodegradation of putrescible material is disregarded.

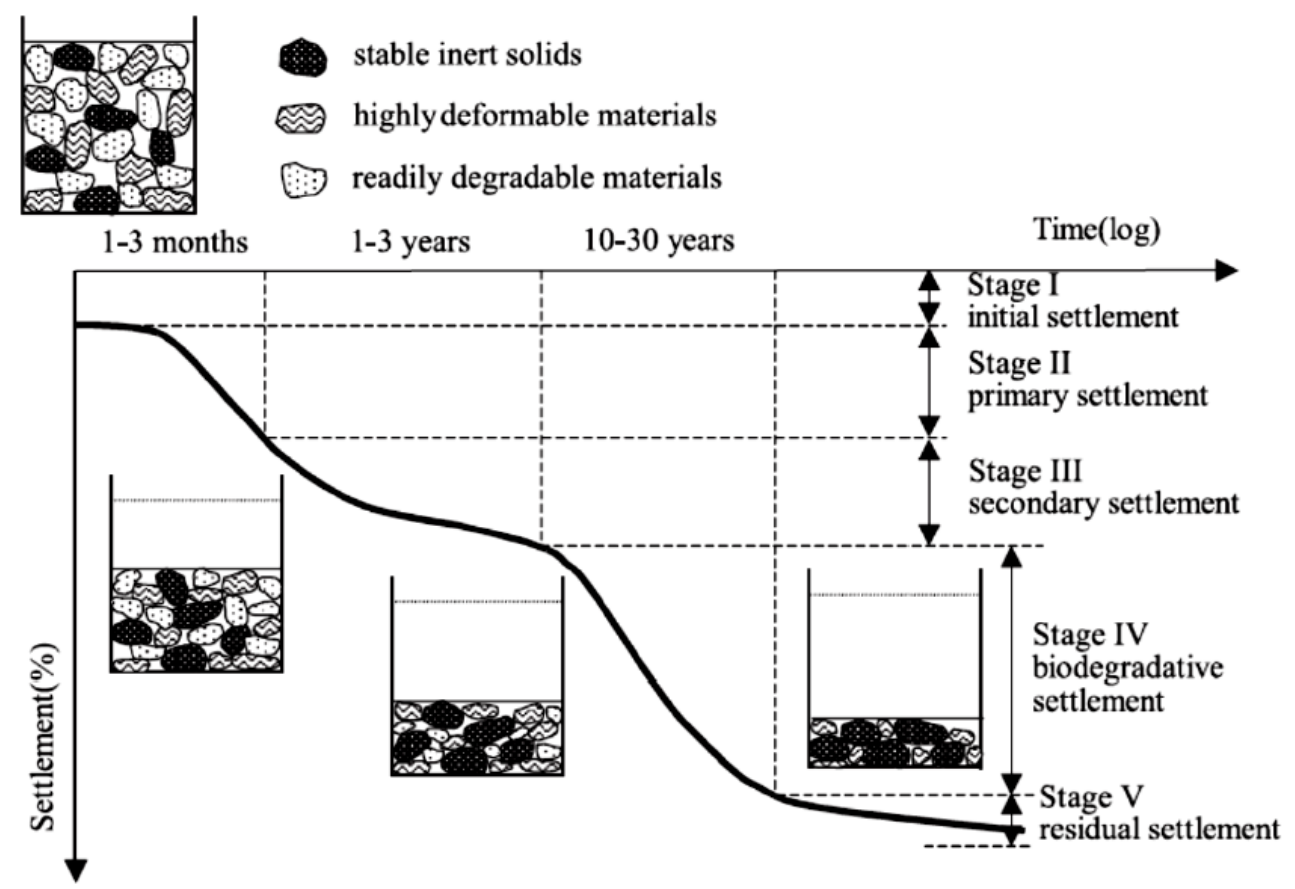

Figure 1: The typical time-settlement data at landfills [9].

There are many investigations associated with the theory and the methods to evaluate the primary and long-term settlements at landfills [10]-[12]. The following equations for estimation the primary $\left(\Delta H_{P}\right)$ and secondary settlement $\left(\Delta H_{S}\right)$ has been presented [11]

$$
\begin{array}{cl}
\Delta H_{P}=H C_{c e} \log \frac{P_{0}+\Delta P}{P_{0}} \quad \text { where } C_{c e}=\frac{C_{c}}{1+e_{0}}, \\
\Delta H_{s}=H_{1} C_{\alpha \varepsilon} \log \frac{t_{2}}{t_{1}} \quad \text { where } C_{\alpha \varepsilon}=\frac{C_{\alpha}}{1+e_{p}},
\end{array}
$$

where, $H$ is the height of waste layer, $H_{1}$ is the height of waste layer at the beginning of the secondary settlement, $C_{c}$ is the primary compression index, $e_{0}$ is the initial voids ratio of waste, $P_{0}$ is the existing pressure at midlevel of layer, $\Delta P$ is the increase in overburden pressure acting at midlevel of layer, $C_{\alpha}$ is the secondary compression index, $e_{p}$ is the void ratio after primary compression, $t_{2}$ is the time, $t_{1}$ is the time which is necessary for primary compression. 


\section{MATERIALS AND METHODS}

The geometry of landfill considered for evaluating the effect of preloading is shown in Fig. 2. According to this section, total height of landfill is $20 \mathrm{~m}$ with $5 \mathrm{~m}$ above the natural ground level and the thickness of cover layer is assumed $0.5 \mathrm{~m}$. As mentioned earlier, in this research, the waste material has been assumed non-putrescible with no biodegradation settlement. In order to calculate the long-term settlement, a detailed numerical analysis using PLAXIS 2D has been carried out, and the results have been verified with those obtained by analytical methods.

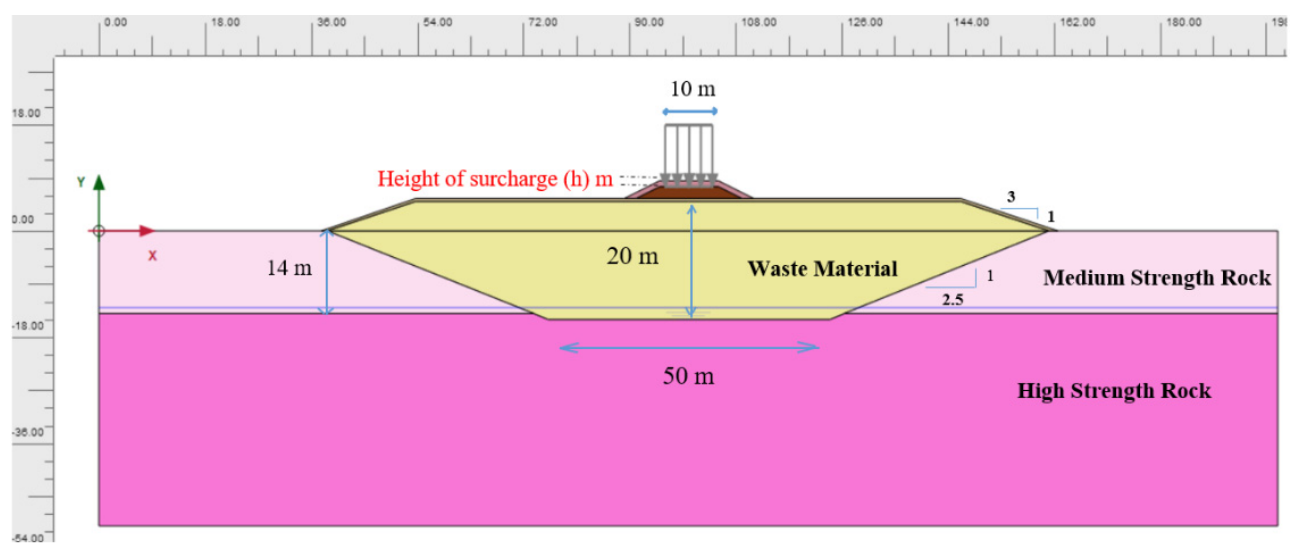

Figure 2: A typical cross section of the proposed landfill.

\subsection{Material}

In order to determine the geotechnical parameters of materials, the most effective parameters are settlement parameters of waste materials, including the primary compression index $C_{c e}$ and the secondary compression index $C_{\alpha \varepsilon}$. There are some references reporting different values for $C_{c e}$ and $C_{\alpha \varepsilon}$ in waste materials. According to Table 1, [13] reported the values of $C_{\alpha \varepsilon}$ for various landfill ages. It can be concluded that values of $C_{\alpha \varepsilon}$ ranges from 0.001 to 0.24 and it is difficult to use one $C_{\alpha \varepsilon}$ for the entire period of landfill. Moreover, there is another literature review conducted by [14]; and data were collected from several published studies. The most recent and relevant data of these investigations are illustrated in Table 2.

Based on the value of settlement parameters, mentioned in the literature, and based on the assumed condition for the waste material (non-putrescible), the geotechnical and design parameters considered for landfill and sub-soil layers are summarized in Table 3.

Table 1: Secondary compression parameters for waste material [13].

\begin{tabular}{|l|c|}
\hline Material & $\boldsymbol{C}_{\boldsymbol{\alpha \varepsilon}}$ \\
\hline Ten year old landfill & 0.02 \\
\hline Fifteen year old landfill & 0.24 \\
\hline Fifteen to twenty year old landfill & 0.02 \\
\hline Old landfill & 0.04 \\
\hline Old landfill with high soil content & 0.001 to 0.005 \\
\hline
\end{tabular}


Table 2: Summary of $C_{c e}$ and $C_{\alpha \varepsilon}$ parameters from literature [14].

\begin{tabular}{|c|c|c|}
\hline $\begin{array}{c}\text { Primary } \\
C_{c e} \\
\end{array}$ & Secondary $C_{\alpha \varepsilon}$ & Reference \\
\hline $0.09-0.19$ & $0.006-0.012$ & {$[15]$} \\
\hline 0.16 & 0.02 & {$[16]$} \\
\hline $0.17-0.24$ & $0.01-0.016$ & {$[17]$} \\
\hline $0.073-0.132$ & $0.015-0.03$ & Field monitoring, [18] \\
\hline $0.17-0.23$ & $0.024-0.030$ & Field monitoring, [19] \\
\hline- & $\begin{array}{c}C_{\alpha \varepsilon(E L)}: 0.02^{\mathrm{a}} \\
C_{\alpha \varepsilon(S W)}: 0.19-0.28^{\mathrm{b}} \\
\end{array}$ & {$[20]$} \\
\hline- & $\begin{array}{c}C_{\alpha \varepsilon(E L)}: 0.014 \text { for waste treated with } \mathrm{DDC}^{\mathrm{c}} \\
C_{\alpha \varepsilon(E L)}: 0.045 \text { for waste treated with surcharge }\end{array}$ & $\begin{array}{l}\text { Field monitoring for } \\
\text { external load [5] }\end{array}$ \\
\hline
\end{tabular}

Table 3: Proposed geotechnical and design parameters for assumed landfill and sub-soil layer.

\begin{tabular}{|c|c|c|c|c|c|}
\hline Material type & $\begin{array}{l}\text { Unit weight } \\
\left(\mathbf{k N} / \mathrm{m}^{3}\right)\end{array}$ & $\begin{array}{c}\text { Effective } \\
\text { cohesion } \\
\text { (kPa) }\end{array}$ & $\begin{array}{c}\text { Effective } \\
\text { friction angle } \\
\text { (degree) }\end{array}$ & $C_{\alpha \varepsilon}$ & $C_{c e}$ \\
\hline Medium strength rock & 21 & 10 & 30 & - & - \\
\hline High strength rock & 21 & 200 & 30 & - & - \\
\hline Waste & 15 & 0 & 30 & 0.02 & 0.15 \\
\hline Cover layer & 20 & 10 & 25 & - & - \\
\hline Embankment & 21 & 2 & 33 & - & - \\
\hline Upper fill (extra surcharge) & 21 & 10 & 30 & - & - \\
\hline
\end{tabular}

\subsection{Methods}

In this research, the numerical simulation is performed using finite element analysis software PLXIS-2D which is a powerful software for two dimensional analysis of deformation in geotechnical engineering. The finite element mesh of the landfill section with 15 node triangular element is shown in Fig. 3.

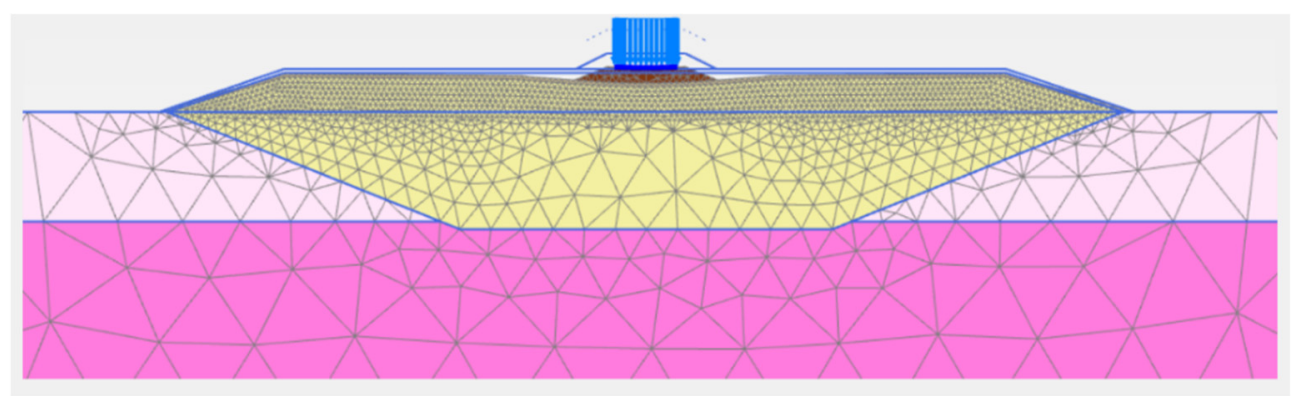

Figure 3: Deformed mesh of the model. 
The soft soil creep (SSC) model has been considered for calculation of creep (secondary settlement). This model is very common for soft soils such as normally consolidated clays, peats and wastes and this model in PLAXIS computes the secondary compression. Since soft soils are highly compressive, in the oedometer test normally consolidated clay behaves ten times softer than normally consolidated sand [21]. In addition, oedometer stiffness of soft soil has linear dependency and in the stress-stiffness curve a line in the form $E_{\text {oed }}=\sigma / \lambda^{*}$ can be plotted, where $\lambda^{*}$ is the modified compression index. The SSC model is an extension of soft soil (SS) model, which is based on Cam Clay model considering Mohr Coulomb criterion for failure. In soft soil (SS) model, increasing the load would cause the stress state to fall outside the current cap and the cap expands instantaneously, while in the SSC model this cap shift needs time. It means that by applying higher load, the cap does not expand immediately and it may take one day to adopt to the new stress state [22]. In order to calculate creep settlement, [23] proposed the following equation:

$$
\varepsilon^{H}=\varepsilon_{C}^{H}+\mu^{*} \cdot \ln \left(\frac{\tau_{c}+t \prime}{\tau_{c}}\right),
$$

where, $\varepsilon_{C}^{H}$ is consolidation settlement, $\mu^{*}$ denotes the creep index describing secondary compression per logarithmic time increment, and $\tau_{c}$ and $t^{\prime}$ are time parameters. The total volumetric strain in an isotropic stress state as a result of increasing the mean effective stress from $p_{0}^{\prime}$ to $p^{\prime}$ during the time of $\left(\tau_{c}+t^{\prime}\right)$ is expressed as:

$$
\varepsilon_{v}=\kappa^{*} \cdot \ln \left(\frac{p^{\prime}}{p_{0}^{\prime}}\right)-\left(\lambda^{*}-\kappa^{*}\right) \cdot \ln \left(\frac{p_{p c}^{\prime}}{p_{p_{0}}^{\prime}}\right)+\mu^{*} \cdot \ln \left(\frac{\tau_{c}+t \prime}{\tau_{c}}\right) .
$$

In eqn (4), the parameters $p_{p_{0}}^{\prime}$ and $p_{p c}^{\prime}$ represent the pre-consolidation pressure relating to before loading and end of consolidation, respectively and $\kappa^{*}$ is the modified swelling, which determines soil behaviour during unloading/reloading. The relationships between basic stiffness $\left(\kappa^{*}, \lambda^{*}, \mu^{*}\right)$ an internationally normalized parameters $\left(C_{r}, C_{c}, C_{\alpha}\right)$ are [24]:

$$
\lambda^{*}=\frac{C_{c}}{2.3(1+e)}, \kappa^{*}=\frac{2}{2.3} \frac{C_{r}}{1+e} \mu^{*}=\frac{C_{\alpha}}{2.3(1+e)} .
$$

\section{RESULTS AND DISCUSSION}

The obtained numerical results for the five evaluated scenarios at three different preloading time are presented in Table 4 . In this table, $h_{s}$ is the surcharge height, which is assumed ranging from $1 \mathrm{~m}$ to $3 \mathrm{~m}$ with $0.5 \mathrm{~m}$ increment in each scenario and $\mathrm{t}_{\mathrm{p}}$ is the preloading time, which is considered to be $3,4.5$, and 6 months. It is obvious that after removing surcharge and applying the reconstruction load, the value of settlement increases with time and this settlement is calculated up to 10 years of applying external load. As an example, the settlement values at Scenario 1 and Scenario 5 of preloading for 3, 4.5, and 6 months preloading time are plotted in Fig. 4. As expected, by increasing preloading time from 3 months to 6 months, the long-term settlement decreased. The maximum of this settlement decrease is $319 \mathrm{~mm}$, which occurred at Scenario 5 of preloading. On the other hand, increasing surcharge height from $1 \mathrm{~m}$ to $3 \mathrm{~m}$ can reduce the settlement with maximum value of $83 \mathrm{~mm}$ for 6 months preloading time.

In order to verify numerical results, a comparison has been performed between numerical and analytical method [11]. Fig. 5 shows this verification for Scenario 1 and Scenario 3 at 3 and 6 months applying preloading. According to these graphs, it can be seen that by increasing the time of applying the reconstruction load, the difference between calculated settlement using theoretical and numerical methods are developing. However, the maximum 


\begin{tabular}{|c|c|c|c|c|c|c|c|c|c|c|c|c|c|c|c|c|c|}
\hline \multirow{11}{*}{ 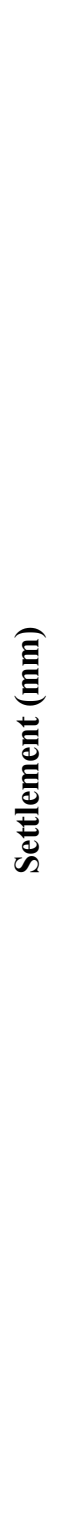 } & \multirow{11}{*}{ 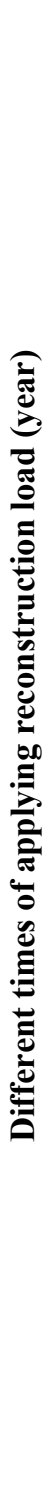 } & 은 & స్ & $\widehat{\widehat{\sigma}}$ & $\bar{\sigma}$ & $\begin{array}{l}\stackrel{\infty}{\infty} \\
\approx \\
=\end{array}$ & $\stackrel{8}{8}$ & $\begin{array}{c}\infty \\
\infty \\
\infty\end{array}$ & $\begin{array}{l}n \\
\simeq \\
=\end{array}$ & $\stackrel{\circ}{\circ}$ & $\begin{array}{l}n \\
\infty \\
\infty\end{array}$ & \begin{tabular}{l}
8 \\
\hdashline \\
$=$
\end{tabular} & $\stackrel{2}{\circ}$ & $\stackrel{n}{+}$ & $\underset{f}{\tilde{\Xi}}$ & $\tilde{\kappa}$ & $\begin{array}{l}\infty \\
\text { N } \\
\infty\end{array}$ \\
\hline & & $a$ & $\underline{\approx}$ & $\underset{-1}{8}$ & $\begin{array}{l}\infty \\
\infty \\
\infty\end{array}$ & $\begin{array}{l}\stackrel{0}{n} \\
\stackrel{n}{=}\end{array}$ & $\stackrel{ా}{\circ}$ & $\begin{array}{l}2 \\
\infty \\
\infty\end{array}$ & $\begin{array}{l}\stackrel{n}{2} \\
\sim \\
-1\end{array}$ & 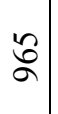 & $\vec{\ddagger}$ & $\begin{array}{l}\cong \\
\approx \\
=\end{array}$ & In & $\bar{\sim}$ & $\begin{array}{l}\stackrel{\Xi}{\Xi} \\
\approx\end{array}$ & $\widehat{\widehat{N}}$ & $\stackrel{\wp}{\infty}$ \\
\hline & & $\infty$ & $\begin{array}{l}n \\
= \\
=\end{array}$ & શิ & $\hat{b}$ & $\begin{array}{l}\stackrel{\text { I }}{\cong} \\
=\end{array}$ & $\begin{array}{l}\infty \\
\approx \\
\sim\end{array}$ & $\begin{array}{c}m \\
\infty \\
\infty\end{array}$ & $\stackrel{\Xi}{\cong}$ & $\hat{\sigma}$ & $\frac{n}{\infty}$ & $\begin{array}{l}8 \\
\ddots \\
=\end{array}$ & $\frac{\infty}{\sigma}$ & $\stackrel{n}{2}$ & 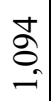 & $\bar{\alpha}$ & $\frac{0}{1}$ \\
\hline & & $r$ & $\underset{\Xi}{\cong}$ & $\stackrel{2}{\circ}$ & $\underset{\infty}{ \pm}$ & $\stackrel{g}{\stackrel{\sigma}{0}}$ & $\stackrel{\infty}{\sim}$ & $\begin{array}{l}n \\
\infty \\
\infty\end{array}$ & $\begin{array}{l}\Omega \\
\delta \\
\sigma\end{array}$ & \begin{tabular}{l}
$\infty$ \\
$\stackrel{2}{2}$ \\
\hdashline
\end{tabular} & $\begin{array}{l}\infty \\
\infty \\
\infty\end{array}$ & 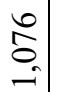 & $\begin{array}{l}\infty \\
\infty \\
\infty\end{array}$ & 2 & రే) & $\stackrel{R}{\infty}$ & $\stackrel{n}{\mathbb{2}}$ \\
\hline & & 6 & 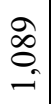 & $\begin{array}{l}0 \\
\sigma\end{array}$ & $\vec{\infty}$ & $\begin{array}{l}\mathbb{J} \\
\stackrel{0}{0} \\
-\end{array}$ & ஓ & $\stackrel{R}{R}$ & $\begin{array}{l}0 \\
2 \\
0 \\
-1\end{array}$ & $\underset{\infty}{\mathbb{N}}$ & 욤 & $\begin{array}{l}0 \\
\text { d } \\
-1\end{array}$ & $\tilde{n}$ & 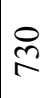 & $\underset{\sim}{\Delta}$ & $\underset{\infty}{\varpi}$ & $\stackrel{0}{1}$ \\
\hline & & in & $\underset{0}{\stackrel{O}{0}}$ & 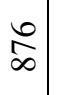 & రె & $\widehat{\widetilde{O}}$ & $\begin{array}{c}n \\
\infty\end{array}$ & $\vec{r}$ & $\begin{array}{l} \pm \\
0 \\
-1\end{array}$ & $\vec{\infty}$ & $\frac{0}{1}$ & $\hat{\alpha}$ & $\stackrel{\circ}{\infty}$ & $\ddot{\infty}$ & $\bar{\infty}$ & $\vec{\Omega}$ & రి \\
\hline & & $\nabla$ & Әे & $\begin{array}{l}\infty \\
\infty \\
\infty\end{array}$ & $\frac{\nabla}{\nabla}$ & ล̃ & 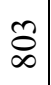 & $\mid \begin{array}{c}1 \\
\infty \\
0\end{array}$ & $\overline{0}$ & $\stackrel{\infty}{\stackrel{\infty}{*}}$ & 8 & $\stackrel{J}{g}$ & 命 & శ్రి & 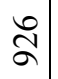 & $\underset{\sim}{\infty}$ & $\frac{9}{6}$ \\
\hline & & $m$ & ळ & ț & $\tilde{\sigma}$ & $\stackrel{2}{2}$ & $\stackrel{\infty}{\curvearrowright}$ & 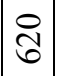 & $\begin{array}{l}n \\
\infty \\
\infty\end{array}$ & $\frac{n}{\pi}$ & $\begin{array}{l}0 \\
\vdots \\
i\end{array}$ & $\underset{\infty}{\mathbb{N}}$ & જิ & 站 & $\begin{array}{l}0 \\
2 \\
\infty\end{array}$ & 尽 & 芯 \\
\hline & & $N$ & $\stackrel{?}{+}$ & $\frac{2}{6}$ & $\begin{array}{l}8 \\
i \\
i n\end{array}$ & $\stackrel{\infty}{\infty}$ & fี & సี & $\stackrel{2}{2}$ & ్ి & $\mid \begin{array}{l}\infty \\
0 \\
0 \\
n\end{array}$ & $\stackrel{n}{\stackrel{2}{2}}$ & $\begin{array}{l}\infty \\
i \\
i\end{array}$ & $\begin{array}{l}n \\
\infty \\
+\end{array}$ & $n$ & $\begin{array}{l}n \\
i n\end{array}$ & $\hat{b}$ \\
\hline & & - & $\frac{n}{6}$ & กิ & $\underset{\sim}{\stackrel{\sim}{f}}$ & $\underset{J}{\mathbb{J}}$ & $\bar{\sigma}$ & $\mid \begin{array}{c}\infty \\
\infty \\
m\end{array}$ & $\tilde{\sigma}$ & $\hat{b}$ & $\vec{b}$ & రి & $\hat{\tilde{\sigma}}$ & $\begin{array}{l}0 \\
m \\
m\end{array}$ & $\frac{9}{i n}$ & $\underset{\nabla}{ \pm}$ & $\frac{0}{n}$ \\
\hline & & $\stackrel{n}{0}$ & $\stackrel{\infty}{\stackrel{\infty}{n}}$ & $\frac{n}{n}$ & ๙ิ & $\stackrel{n}{\frac{n}{\sigma}}$ & $\underset{m}{\forall}$ & $\stackrel{0}{2}$ & $\stackrel{+}{\sim}$ & $\frac{n}{m}$ & ন্ & શे & ঐ & $\stackrel{\infty}{\stackrel{\nu}{~}}$ & \begin{tabular}{l}
$\infty$ \\
\multirow{8}{*}{} \\
\end{tabular} & ڤ્సे & $\hat{\infty}$ \\
\hline & & & $m$ & ?? & 0 & $m$ & $\stackrel{n}{+}$ & b & $m$ & $\mid$ & 0 & $\infty$ & $\stackrel{n}{\sim}$ & 6 & $m$ & 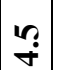 & 0 \\
\hline & 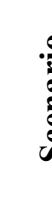 & & & $\begin{array}{l}\Xi \\
\text { II } \\
\cong \\
\cong\end{array}$ & & & 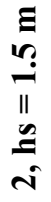 & & & 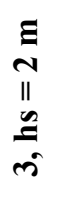 & & & 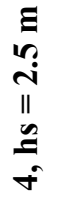 & & & 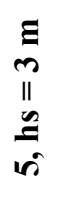 & \\
\hline
\end{tabular}


88 Waste Management and the Environment X

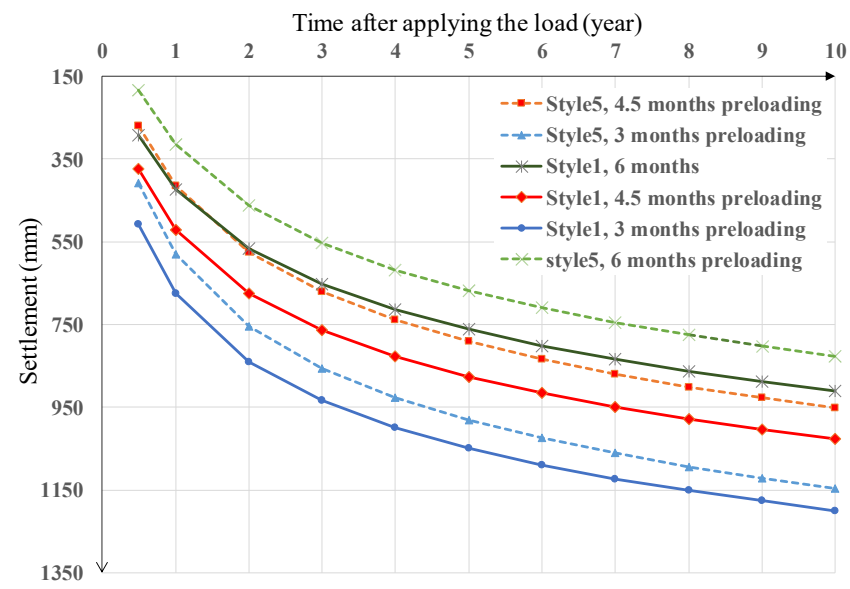

Figure 4: Settlement versus time after applying the reconstruction load at Scenario 1 and Scenario 5 preloading.

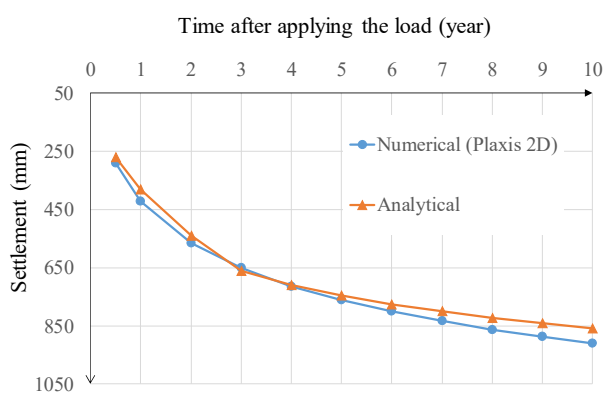

(a)

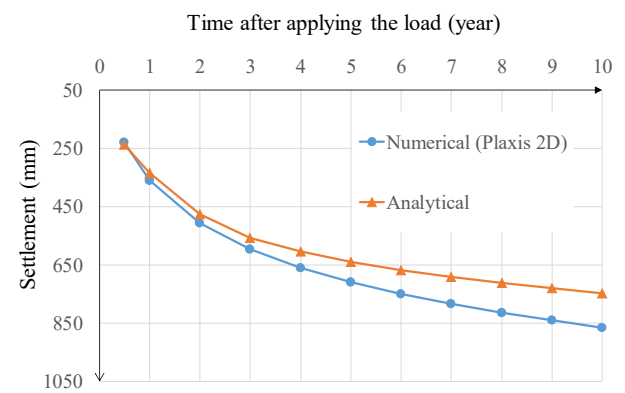

(c)

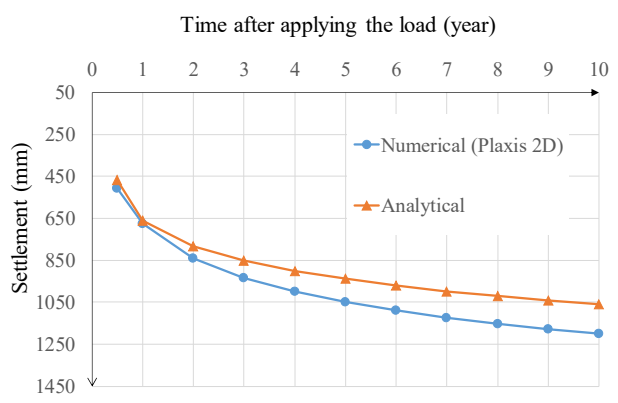

(b)

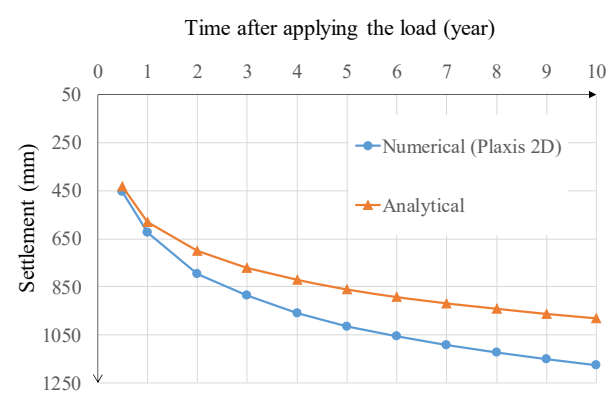

(d)

Figure 5: Verification of numerical results with analytical results. (a) Scenario 1, 6 months; (b) Scenario 1, 3 months; (c) Scenario 3, 6 months; and (d) Scenario 3,3 months.

value of this difference which is related to Scenario 3 and 3 months preloading, is limited to $17 \%$ and this value of disagreement is reasonable. Therefore, the numerical and analytical results are in acceptable agreement with each other. 


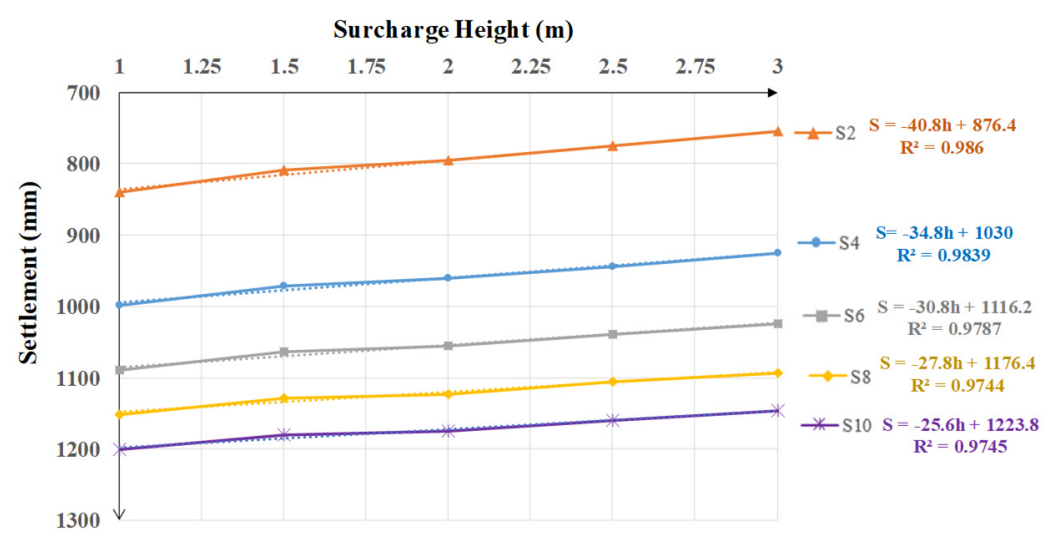

(a)

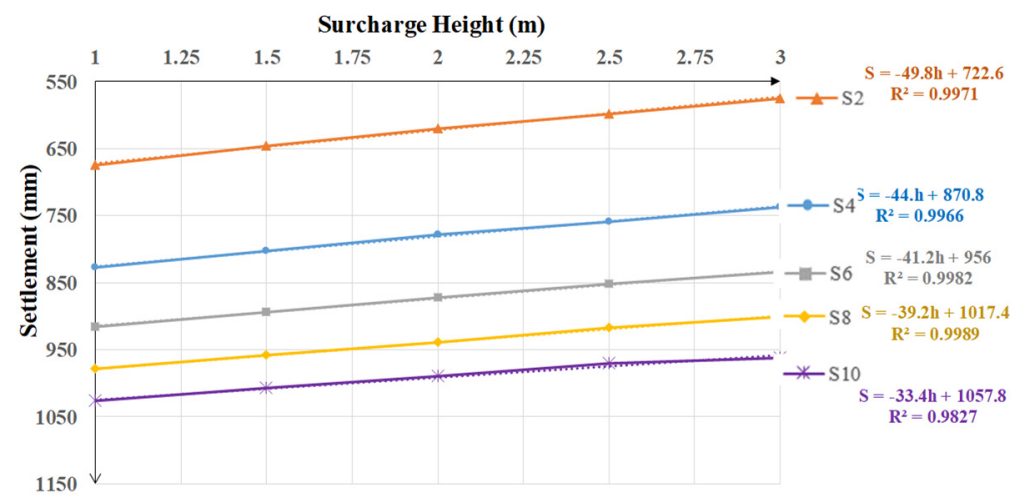

(b)

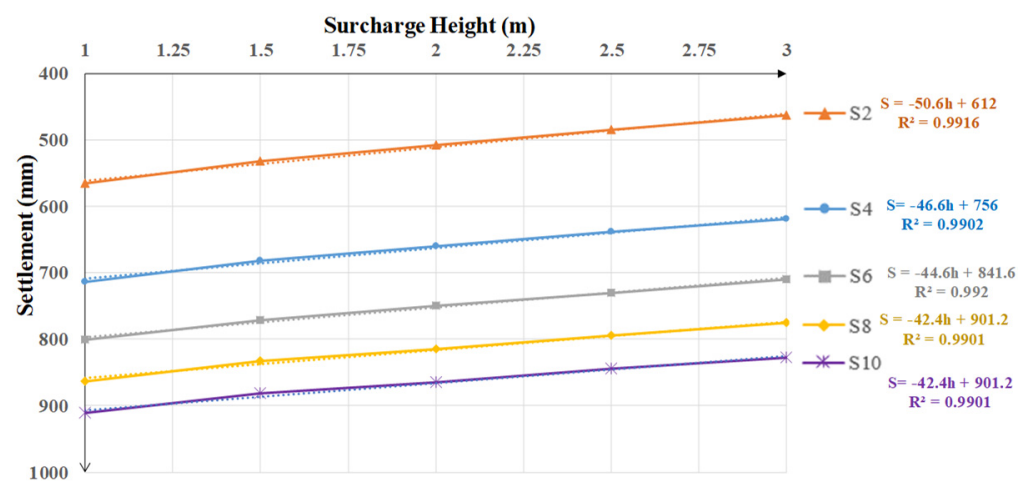

(c)

Figure 6: Settlement versus surcharge height for 2, 4, 6, 8 and 10 years after applying the reconstruction load. (a) 3 months; (b) 4.5 months; and (c) 6 months. 
In Fig. 6, the variation of settlements versus surcharge height after different times of applying reconstruction load $(2,4,6,8$, and 10 years) are presented. According to these graphs, there is approximately a linear relationship between the long-term settlement and the height of surcharge, and the corresponding equation is presented close to each graph. On the other hand, the rate of settlement reduction decreases by increasing the time of applying external load, indicating that in the first years of applying reconstruction loads, increasing the surcharge height has more effect on decreasing settlements. In order to evaluate the effect of preloading time and surcharge height in reducing the settlement of landfills under reconstruction loads, the settlement values after 10 years of applying external loads and preloading time for different scenarios of preloading (different surcharge heights) are plotted in Fig. 7. Based on the obtained results, by increasing the preloading time for 1.5 months, the long-term settlement decreases about $15 \%$ while by increasing the surcharge height from $1 \mathrm{~m}$ to $3 \mathrm{~m}$, the settlement values decrease approximately $5 \%$. As a result, by comparing these two crucial parameters in the preloading ground improvement method, it can be concluded that the preloading time is a more important factor compared to the surcharge height in curtailing the settlement.

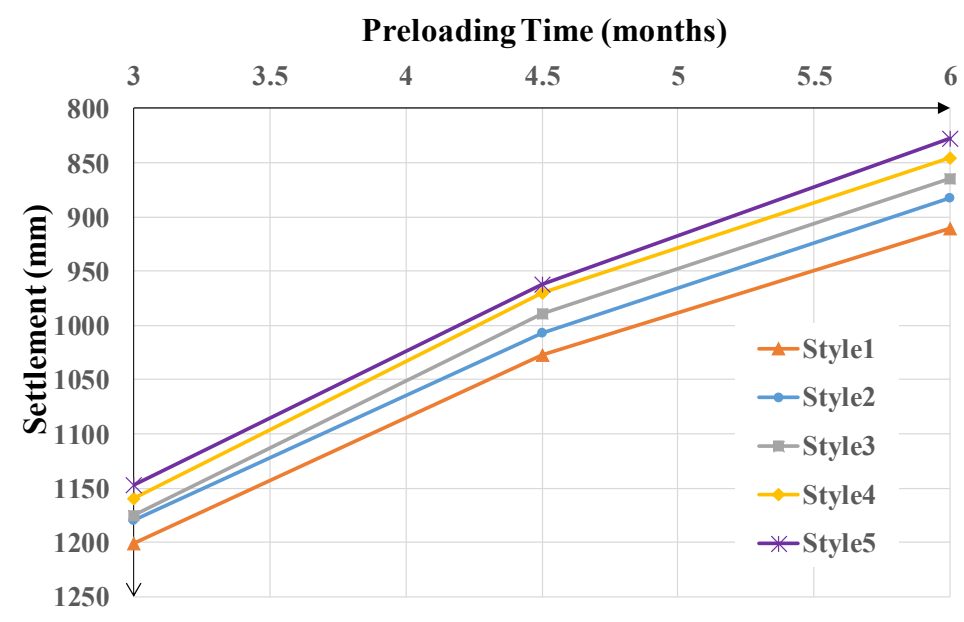

Figure 7: Settlement versus preloading time for different surcharge scenarios.

\section{CONCLUSIONS}

Preloading is a non-intrusive ground improvement technique at closed landfill sites, which can prevent damages to the landfill structures, such as drainage systems and liner cover, under reconstruction loads. In this method, height and time of applying surcharge are two crucial factors to save time and make projects be cost effective. In other words, by selecting a proper combination of height and time of preloading, the time of ground improvement method can be reduced, while the project costs can be kept under control. In this research, the effects of these two factors on long-term settlement of waste material deposits have been investigated by conducting an array of numerical analyses with PLAXIS 2D. The predicted results were verified with an existing theory of settlement. In the assumed conditions, the results indicated that, preloading time was a more effective parameter compared to the surcharge height. Moreover, the settlement values for different surcharge height varied linearly; and this linear relationship was developed for each fitted line. 
To conclude, in projects in which preloading is a proposed method of ground improvement, a reasonable combination of preloading height and time can be opted by considering the maximum allowable settlement. There might be some time, cost, and construction limitations in some projects, which can affect the optimum combination of preloading time and height. Hence, waste materials can be managed for reconstruction purposes by adopting preloading method as a non-intrusive method to control long-term settlement of landfills. Since preloading approach does not disturb the internal systems of closed landfills (e.g. cover, drainage, liner, gas collection and leachate collection systems), it can be considered for redevelopment in areas with land scarcity employing environmental concerns.

\section{REFERENCES}

[1] Bouazza, A. \& Van Impe, W.F., Ground modification methods applied to municipal solid waste landfills. Australian Geomechanics, pp. 73-83, 1997.

[2] Moseley, M.P. \& Kirsch, K., Ground Improvement, 2nd ed., Taylor and Francis, 2004.

[3] Mohamad, R., Precompression of soft soils by surcharge preloading: Some common pitfalls and misunderstood fundamentals, 2008.

[4] De Melo, L., El-Sherbiny, R., Steier, W. \& Salem, M., Evaluation of waste compressibility due to preloading at the Fresh Kills Landfill. GeoCongress 2012: State of the Art and Practice in Geotechnical Engineering, pp. 4184-4193, 2012.

[5] Lewis, P.J., Mansfield, J., Ashraf, S. \& Zicko, K., Performance of a highway embankment constructed over landfill material. Proceedings of the Fifth International Conference on Case Histories in Geotechnical Engineering, New York, 2004.

[6] Mitchell, J.K. \& Van Court, W.A., Role of soil modification in environmental engineering applications. Geotechnical Special Publication, 1(30), pp. 110-143, 1992.

[7] Tahmoorian, F., Development of a technical management tool for settlement and stability behaviour of municipal solid waste landfills. Master's thesis, University of Technology Sydney, Australia, 2014.

[8] Emberton, J. \& Parker, A., The problems associated with building on landfill sites. Waste Management and Research, 5(1), pp. 473-482, 1987.

[9] Grisolia, M., Napoleoni, Q. \& Tangredi, G., The use of triaxial tests for the mechanical characterization of municipal solid waste. Proceedings of the Sardinia 1995, Fifth International Landfill Symposium, 2, pp. 761-767, 1995.

[10] Ling, H.I., Leshchinsky, D., Mohri, Y. \& Kawabata, T., Estimation of municipal solid waste landfill settlement. Journal of Geotechnical and Geoenvironmental Engineering, 124(1), pp. 21-28, 1998.

[11] Sowers, G.F., Settlement of waste disposal fills. Proceedings of the 8th International Conference on Soil Mechanics and Foundation Engineering, Moscow, pp. 207-210, 1973.

[12] Dodt, M.E., Sweatman, M.B. \& Bergstorm, W.R., Field measurements of landfill surface settlements. Geotechnical Practice for Waste Disposal, ASCE, Reston, VA, 7, pp. 406-417, 1987.

[13] Oweis, I.S. \& Khera, R., Geotechnology of Waste Management, 2nd ed., PWS Publishing Company, 1998.

[14] Sharma, H.D. \& De, A., Municipal solid waste landfill settlement: Postclosure perspectives. Journal of Geotechnical and Geoenvironmental Engineering, 133(6), pp. 619-629, 2007. 
[15] Boutwell, G.P. \& Fiore, V.A., Settlement of clay cover on saturated garbage. Geoenvironment 2000: Characterization, Containment, Remediation, and Performance in Environmental Geotechnics, ASCE, pp. 964-979, 1995.

[16] Stulgis, R.P., Soydemir, C. \& Telgener, R.J., Predicting landfill settlement. Geoenvironment 2000, Geotechnical Special Publication ASCE, 2(1), pp. 980-994, 1995.

[17] Landva, A.O., Valsangkar, A.J. \& Pelkey, S.G., Lateral earth pressure at rest and compressibility of municipal solid waste. Canadian Geotechnical Journal, 37(6), pp. 1157-1165, 2000.

[18] Marques, A.C.M., Filz, G.M. \& Vilar, O.M., Composite compressibility model for municipal solid waste. Journal of Geotechnical and Geoenvironmental Engineering, 129(4), pp. 372-378, 2003.

[19] Andersen, E.O., Balanko, L.A., Lem, J.M. \& Davis, D.H., Field monitoring of the compressibility of municipal solid waste and soft alluvium. International Conferences of Case Histories in Geotechnical Engineering, 2004.

[20] Sharma, H.D., Solid waste landfills: Settlements and post-closure perspectives. Environmental and Pipeline Engineering, pp. 447-455, 2000.

[21] Gündüz, B., Analysis of settlements of test embankments during 50 years: A comparison between field measurements and numerical analysis. Master's thesis, Lund University, 2008.

[22] Waterman, D. \& Broere, W., Practical application of the soft soil creep model. Plaxis Bulletin, 15, 2004.

[23] Butterfield, R., A natural compression law for soils. Géotechnique, 29(4), pp. 469480, 1979.

[24] Neher, H., Wehnert, M. \& Bonnier, P., An evaluation of soft soil models based on trial embankments. Computer Methods and Advances in Geomechanics, ed. C. Desai, AA Balkema: Rotterdam, pp. 373-378, 2000. 